\title{
DROUGHTS IN THE TIETÊ-PARANÁ WATERWAY: IMPACTS ON THE DIRECT, INDIRECT AND HIDDEN COSTS IN THE TRANSPORTATION OF SOYBEAN
}

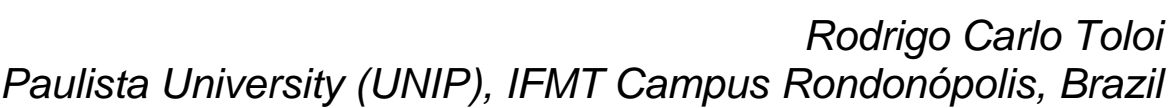

E-mail: toloirodrigo@gmail.com

Moacir Freitas Junior FATEC ZS, Paulista University (UNIP), Brazil

E-mail: bicimo@uol.com.br

João Gilberto Mendes dos Reis Paulista University (UNIP), Brazil

E-mail: jgilbertomreis@unip.br

Oduvaldo Vendrametto Paulista University (UNIP), Brazil

E-mail: oduvaldov@unip.br

Pedro Luiz Oliveira Costa Neto Paulista University (UNIP), Brazil E-mail: politeleia@uol.com.br

Submission: $18 / 12 / 2015$

Revision: 03/01/2016 Accept: 11/01/2016

\section{ABSTRACT}

Brazil's agricultural economy is growing and increasing productivity. Therefore, it has required transportation systems with high load capacity and lower transportation costs. However, with the drought in the Southeast region of Brazil, the waterway Tietê-Paraná closed since May 2014 generating a loss of more than 30 million last year. Thus, this study investigates the impacts on direct, indirect and hidden costs resulting from this change of route for soy transport. The methodology consists of an exploratory, descriptive and bibliographic research that seeks to raise the main costs. The results show that failing to ensure the production of soybeans by the Tiete-Parana waterway and using the highway transportation costs for waterway users are increased by US\$37,760,146.86. 
DOI: 10.14807/ijmp.v7i2.418

Keywords: Logistics; Soy; Waterways; Costs

\section{INTRODUCTION}

River transport has been considered an inexpensive and low-energyconsuming means of transportation (POMPERMAYER; CAMPOS NETO; PAULA, 2014). Moreover, it is efficient for transporting bulk goods of low benefit such as iron ore, grains, and commodities in general.

Countries such as Argentina and the US have been using their main waterways to facilitate the transportation of grains (SCHNEPF, 2001), being able to offer more competitive prices when compared to the grains produced in Brazil, where they use instead road and rail transport.

Brazil owns over 39,146 miles of waterways from which between 24,854 e 31,068 miles of river, lakes and lagoons can be considered potentially navigable. However, nowadays, a little more than 8,077 miles are used for navigation (SCHNEPF, 2001; TEIXEIRA, 2010). The United States, for instance, use 13,670 miles of waterways, being those 2,348 miles belong to only Mississippi River. These waterways are responsible for transporting 600 million metric tons of cargo per year (WORLD WIDE INLAND NAVIGATION NETWORK - WWINN, 2015). In Brazil, waterways were responsible for transporting 80,3 million of metric tons in 2013 (AGÊNCIA NACIONAL DE TRANSPORTE AQUAVIÁRIOS-ANTAQ, 2013).

In Table, I, am possible to see the main Brazilian waterways used and adequacy issues, aids-to-navigation issues, lack of shipping locks and nonobservance of the environmental law are among the many problems they face (AMARAL; CORDEIRO NETTO, 2013).

The drought in Brazilian waterways began in 2013 has been affecting transportation by rivers. Tietê-Paraná waterway, for instance, has stopped its activities due to the drought resulting in a loss of US $\$ 50,816,881.37$. From January to July 2014, the number of shipments that are no longer performed by this waterway was 2.69 million metric tons and this difference amounts to 72 mil trucks (TOMAZELA, 2014). 
DOI: 10.14807/ijmp.v7i2.418

Table 1: Main Brazilian waterways

\begin{tabular}{|c|c|c|c|c|}
\hline Waterways & Rivers & $\begin{array}{l}\text { Length } \\
\text { (miles) }\end{array}$ & Interconnected & ties \\
\hline Madeira & Madeira River & 656 & Porto Velho/RO & Itacoatiara/AM \\
\hline Tietê-Paraná & $\begin{array}{l}\text { Paranaíba River, Paraná } \\
\text { River, Tietê River }\end{array}$ & 1,491 & São Simão/GO & $\begin{array}{l}\text { Conchas/SP, Santa } \\
\text { Maria da Serra/SP }\end{array}$ \\
\hline $\begin{array}{l}\text { Paraguai- } \\
\text { Paraná }\end{array}$ & $\begin{array}{l}\text { Paraguai River, Paraná } \\
\text { River, Cuiabá River }\end{array}$ & 2,138 & Cáceres/MT & $\begin{array}{l}\text { Buenos } \\
\text { Aires/Argentina }\end{array}$ \\
\hline San Francisco & São Francisco River & 851 & Pirapora/MG & $\begin{array}{l}\text { Juazeiro/BA, } \\
\text { Petrolina/BA }\end{array}$ \\
\hline $\begin{array}{l}\text { Tocantins- } \\
\text { Araguaia }\end{array}$ & $\begin{array}{l}\text { Araguaia River, } \\
\text { Tocantins River }\end{array}$ & 786 & Cocalinho/MT & $\begin{array}{l}\text { Pedro Afonso/TO, } \\
\text { Estreito/MA }\end{array}$ \\
\hline $\begin{array}{l}\text { Waterways in } \\
\text { the South }\end{array}$ & $\begin{array}{l}\text { Jacuí River, Taquari } \\
\text { River, Jaguarão River, } \\
\text { Lagoa dos Patos River, } \\
\text { Lagoa Mirim River. }\end{array}$ & 559 & Porto Alegre/RS & $\begin{array}{l}\text { Rio Grande/RS, } \\
\text { Pelotas/RS, } \\
\text { Jaguarão/RS }\end{array}$ \\
\hline
\end{tabular}

Currently, Tietê-Paraná waterway is closed due to the drought causing 4 million metric tons of grains to be transported by trucks, consequently, resulting in a US\$ 14,482,811.19 (TREVISAN, 2015).

In that scenario, this study has as its central issue: What are direct, indirect and hidden costs created by the stoppage of Tietê-Paraná waterway? In order to answer that question, this study aims at investigating what those costs are and how they affect the transportation of grains that takes place between São Simão/GO and Pederneiras/SP Ports.

\section{WATERWAY TRANSPORT}

The matrix of transport modes in Brazil is dominated by road transportation, which is responsible for transporting about $60 \%$ of all cargo at a high cost. (WANKE, 2010).

Waterway transportation is the means by which it is possible to transport for a long distance a great amount of goods such as minerals, gravels, sand, coal, iron, grains and other non-perishable products. According to Dias (2010), waterway transportation is made by great-size barges transporting cargo between domestic ports, operating in seaports and river ports, nationwide or long-distance and internationally. 
DOI: 10.14807/ijmp.v7i2.418

The ships and barges have a relatively great capacity, the fixed costs are absorbed by the vast amount of products and, as Chopra and Meindl (2011) suggest, its main advantage is the low cost.

Brazilian transport system is managed by ANTAQ (Brazilian Waterway Transport Agency). According to ANTAQ, Brazilian waterways transported 315,4 million metric tons, between 2010 and 2013, Figure 1.

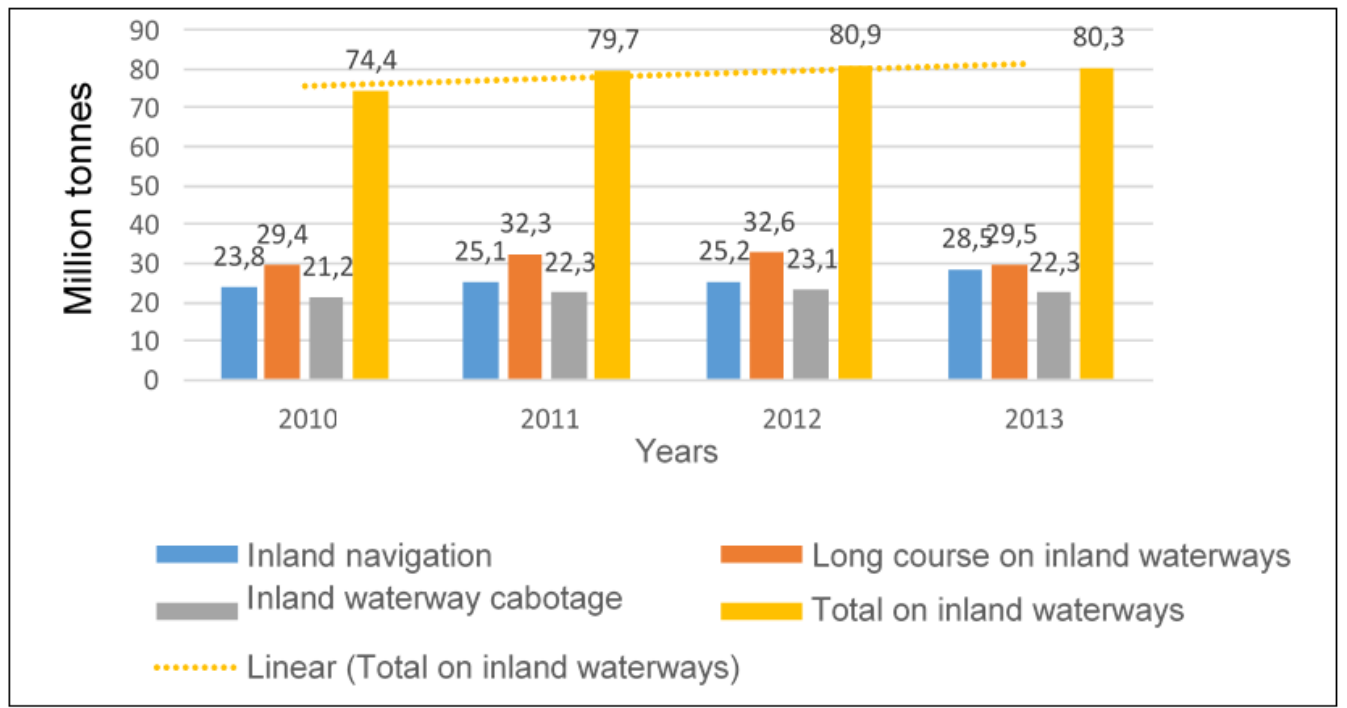

Figure 1: Tonnes Transported through Waterways in Brazil between 2010 and 2013. Source: Adapted from ANTAQ (2014)

Among the main goods transported are iron ore, soy, fuel, and corn, as can be seen in Figure 2.

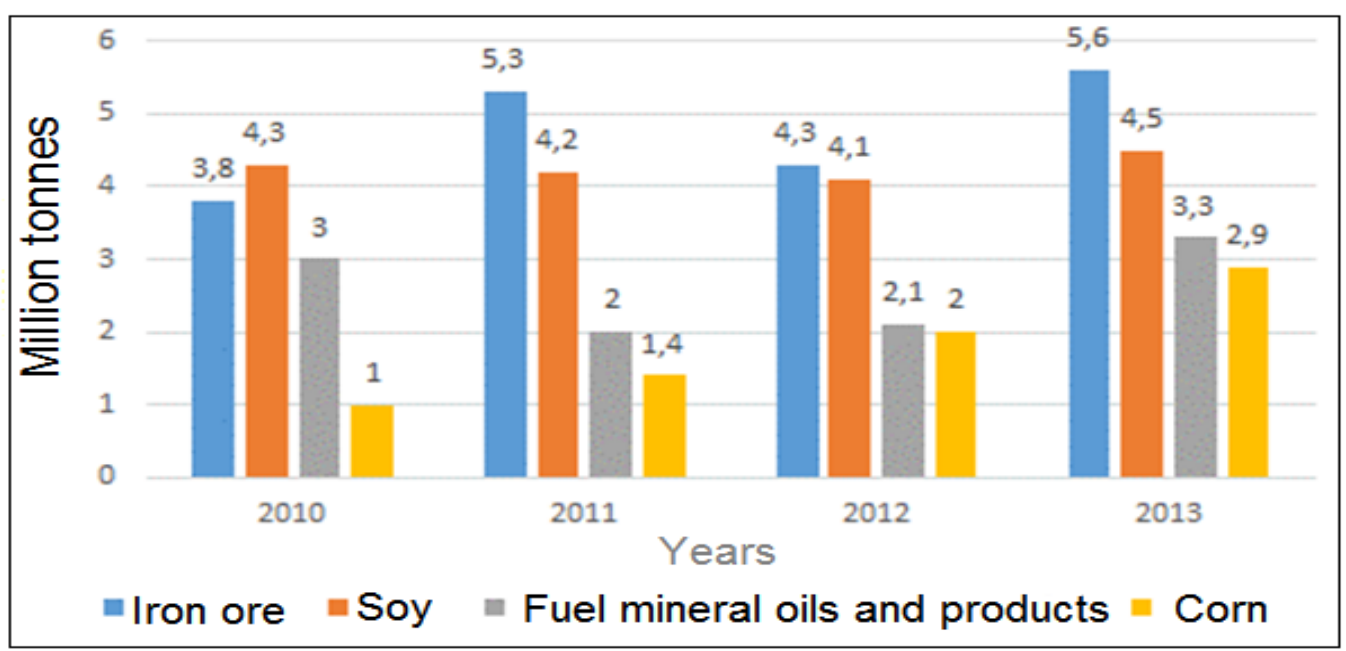

Figure 2: Main Products Transported by Waterways between 2010 and 2013. Source: adapted from ANTAQ (2014) 
DOI: 10.14807/ijmp.v7i2.418

\subsection{Tietê-Paraná Waterway}

The Tietê-Paraná Waterway is responsible for transporting about 8 million metric tons of cargo, from which 2 million metric tons are soy and corn (TREVISAN, 2015).

The navigation on Tietê and Paraná Rivers began before Portuguese colonization in Brazil since Indians already used to use it for commuting and fishing. Their geographical position hindered medium and long distance navigation and people were forced to do that journey on foot, on horseback or horse cart.

According to TEIXEIRA (2010), in the last 50 years, São Paulo State Government built several multiple-use constructions such as ship locks, opened channels to boost navigation and spread navigation signaling all through the waterway. Such efforts resulted in the consolidation of an integrated waterway transport system, associated with a road and rail transport network in a process of integration and modernization.

The transportation through Tietê-Paraná Waterway is by barges destined to ports and processing plants. This system owns about 1,491 miles of waterway between Conchas and Piracicaba (SP) all the way to Goiás and Minas Gerais (to the north) and Mato Grosso do Sul, Paraná and Paraguay (to the south).

This waterway has six hydroelectric power stations and eight ship locks at Tietê River, and for more stations and two ship locks at Paraná River. They also own 23 bridges, 19 shipyards and 30 intermodal terminals managed by the private sector, which are used for temporarily storing raw material or processing it. Such infrastructure made the waterway mode an economical alternative for cargo transport besides propitiating the reordering of transport matrix in the central-western São Paulo and propelling the regional development of cities like Barra Bonita and Pederneiras (TEIXEIRA, 2010).

This assignment aimed at Tietê-Paraná Waterway, bearing in mind its operations stoppage due to problems caused by the drought, which demand transportation be made by other modes, influencing the direct, indirect and hidden costs. 
DOI: 10.14807/ijmp.v7i2.418

\subsection{Transportation Costs}

As Kussano (2012) points out the transportation costs are those that involve handling of inputs and raw material from the suppliers to the delivery of the finished product and they are capital costs (depreciation, financial obligations, rates of return), operational costs (maintenance, supervision, staff, lease, insurances) among others (taxes, tolls, licenses).

Carvalho (2010) states that the transportation costs must be dealt with upon two perspectives: (i) the perspective of the user (contractor) and (ii) the operating company (the fleet owner). In the first case, the company which outsources the transport operations (or part of them), bearing in mind the costs of transport as variables; in the second case, though, as operator (fleet owner), the transport costs have a fixed amount and a variable portion.

According to ILOS (Instituto de Logística e Supply Chains, 2014), the costs can vary according to the transportation mode employed, since each mode has its costs variations, representing $4,7 \%$ in relation to the net income of the companies in Brazil, as can be seen in Figure 3.

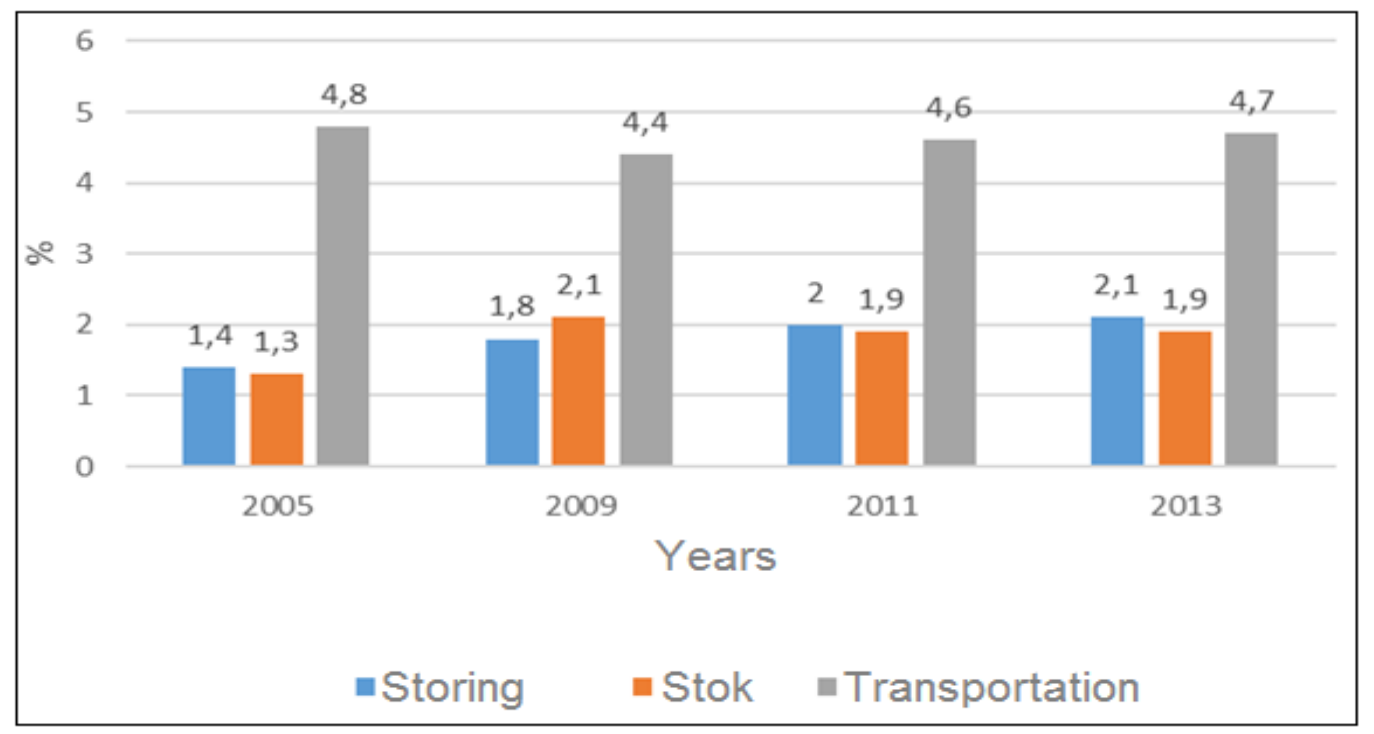

Figure 3: Logistical costs in relation to net income. Source: ILOS (2014)

\section{RESEARCH METHODOLOGY}

This work consists of an exploratory research, which aims at studying the current situation of the waterway and showing the impacts of the drought in the transportation of grains. 
DOI: 10.14807/ijmp.v7i2.418

This assignment consisted of the following steps:

a) A bibliographic research, which enabled the identification of:

I.The direct, indirect and hidden costs with reference to the use of waterway mode under normal circumstances;

II. The cost of the road mode for transporting grains from São Simão/GO to Pederneiras/SP.

b) The making of a comparative study based on data gathered, which enabled the showing of the impacts resulting from the change from the waterway mode to the road mode for soy transport, caused by the drought.

\section{FINDINGS AND DISCUSSION}

Brazil is one of the biggest soybean producers, a competitive asset essential for trading balance. However, direct, indirect and hidden costs interfere directly in the Brazilian soy market competitiveness.

According to Reis, Toloi, and Freitas (2015), the cost of waterway transport is only US $\$ 0.003 \mathrm{t} / \mathrm{km}$, whereas the cost of rail transport is US $\$ 0.018$ ton- $\mathrm{km}$ and the road one is US $\$ 0.028$ ton-km. thus, the activities stoppage in that waterway results in a direct cost of US\$ 0.025 tone-km in the freightage.

In order to evince such impact, below the costs involved in this stoppage are discussed by the following concepts: direct, indirect and hidden costs.

\subsection{Direct and Indirect Costs}

According to Dutra (2010), all expenses related to goods and service used in the production of other goods or services are considered costs. The expenses have the peculiarity to look similar, but in practice, they can be classified as direct costs when used directly in the production process of a good or service and indirect when used in the support operations, and can be classified as fixed and variable.

Direct cost is that which can be calculated in the moment of its occurrence, for instance, the truck driver's salary in road transportation. The indirect cost is the opposite: we are not able to calculate it when it occurs and, subsequently, by means of an assessment it can be accounted: mechanical maintenance and tire wear, for instance. Table 2 shows the main direct and indirect costs in transportation. 
DOI: 10.14807/ijmp.v7i2.418

Table 2: Direct and Indirect Costs in Transport

\begin{tabular}{|c|c|}
\hline Direct & Indirect \\
\hline Depreciation & Administration \\
\hline Capital stock & Fuel \\
\hline Crew salary & Tyres \\
\hline $\begin{array}{c}\text { Insurance } \\
\text { Taxes (vehicles) }\end{array}$ & $\begin{array}{l}\text { Lubrication } \\
\text { Maintenance }\end{array}$ \\
\hline
\end{tabular}

Direct costs are those, which can be calculated at the moment they occur. As an example, the longevity of a barge is 20 years with an annual depreciation tax of $5 \%$, whereas a truck's life span is five years with an annual depreciation tax of $20 \%$. Indirect costs are those, which can only be calculated only afterwards, such as fuel expenses, by means of an apportionment. While a truck consumes 96 liters of fuel in tons per kilometer, a tugs consumes only 5 liters according to the Waterway Plan of MT (TRANSPORT MINISTRY, 2013).

Waterway transport is more efficient energy-wise, provides large concentration of cargo, longer lifespan of vehicles and their infrastructure and maintenance costing US\$ 0.003 per $\mathrm{km}$ in comparison with road transport's US\$ 0.028 cost, and consumes less fuel, emits a smaller amount of pollutants, does not create traffic, shows a smaller rate of accidents and low noise emissions.

Table 3 shows the cost per metric ton for soybean transport, the city of Juína, located in the northwestern region of the state of Mato Grosso, to the port of Santos / SP.

The table shows the costs of using transportation waterway, road and railway for the transportation of production the soybean. Through the data, it concludes that the financial cost of transport waterway is less than other modes of transport.

Table 3: Costs of the transportation modals.

\begin{tabular}{|c|c|c|c|c|}
\hline City Region & Transport route & $\begin{array}{c}\text { Distance } \\
\text { (km) }\end{array}$ & $\begin{array}{l}\text { Cost } \\
\text { t/km }\end{array}$ & $\begin{array}{l}\text { Cost transport } \\
\text { metric ton }\end{array}$ \\
\hline \multirow{4}{*}{$\begin{array}{l}\text { Juína } \\
\text { northwestern }\end{array}$} & Transport Road & 1.533 & US\$ 0,028 & $\mathrm{R} \$ 168,63$ \\
\hline & y (São Simão / GO & & & \\
\hline & Transport Railway (Pederneiras / SP _ & 64 &, 003 & Rq \\
\hline & Santos / SP) & 496 & US\$ 0,018 & $\mathrm{R} \$ 34,72$ \\
\hline
\end{tabular}

Source: Adapted from USDA (2012), Pompermayer, Campos Neto and De Paula (2014) and Reis et al. (2015). 
DOI: 10.14807/ijmp.v7i2.418

Waterway transport proves to be more economical in relation to road mode, since it presents smaller costs in the environment impacts, from its design to its operation, smaller pollutant emissions, less lubrication use, non-necessity of tires, not existence of road tolls, less maintenance cost in all its extension, less risk of theft.

In addition to the financial advantage transportation of waterway and utilizing the parameter in relation to cargo space, with equivalent cargo units, the waterway presents a quite significant advantage, because, a composition, double of four barges and a tug can transport 6,000 metric tons at the same amount of time of the rail mode: there would have to be 2.9 Hopper trains with 86 wagons weighing 80 metric tons and if the same volume were transported by road mode, we would need 172 bi train dolly trucks weighing 35 metric tons each (PROTASIO, 2015).

Besides environmental, financial and economical advantages, the waterway mode stands out, as can be seen in Table 4 .

Table 4: Advantages of waterway transport among the other modes

\begin{tabular}{|c|c|c|c|}
\hline Characteristics & Barges & Train & Truck \\
\hline Dead weight per ton transported & & $800 \mathrm{~kg}$ & $700 \mathrm{~kg}$ \\
\hline Traction force - $1 \mathrm{cv}$ & $4.000 \mathrm{~kg}$ & $500 \mathrm{~kg}$ & $150 \mathrm{~kg}$ \\
\hline $\begin{array}{l}\text { Amount of equipment for } \\
\text { transporting a thousand metric } \\
\text { tons }\end{array}$ & $\begin{array}{l}1 \text { tug and } 1 \\
\text { ferry }\end{array}$ & $\begin{array}{l}1 \text { engine and } 50 \\
\text { wagons }\end{array}$ & $\begin{array}{l}50 \text { truck-tractors e } 50 \\
\text { trailers }\end{array}$ \\
\hline $\begin{array}{l}\text { Distance }(\mathrm{km}) \text { covered with } 1 \text { litter } \\
\text { of fuel and } 1 \text { ton cargo }\end{array}$ & $219 \mathrm{~km}$ & $86 \mathrm{~km}$ & $25 \mathrm{~km}$ \\
\hline Lifespan in years & 50 & 30 & 10 \\
\hline
\end{tabular}

Considering its capacity for storing, waterway transport shows advantages, due to the fact the tug of barge can transport up to 1,500 metric tons of cargo and, compared to road transport, each barge equals to 60 trucks, which can transport no more than 25 tons.

\subsection{Hidden Costs}

Souza et al. (2015) defines hidden costs as those that are neither realized nor calculated in a logistical context, invisible to managers, and have a negative effect on the result of the company and originate from a non-compliance and are disregarded in the general accounting due to lack of data control and failure in identifying them. 
DOI: 10.14807/ijmp.v7i2.418

Thus, determine the indirect costs by means of apportionment is not real in relation to the cost data preciseness in the companies, but determining the origin of those costs in order to work them aiming at its correct calculation and, subsequently, a reduction of the amount they represent. When it comes to soybean draining these costs can be summarized as follows on Table 5 .

Table 5: Hidden Costs in Soy Transport due to the Stoppage of Tietê-Paraná Waterway

\footnotetext{
Activity Reasons

Field

Storing

Operation

Transport

Unloading

Export

The combines lose on average $1 \%$ of operation volume

Birds, humidity, cleaning, rats, product deterioration, pests and insects: losses can reach $5 \%$

Realease of vehicles for loading and shipping, inadequate equipment use, not properly trained staff

Restrictions to road traffic, gridlock in cities, breakdown, and maintenance caused by the aging of equipment, overload, adaptations in the wooden truck body, loss of grains along the journey, with rough roads and unsuitable truck bodies those losses can hit $2 \%$ of all cargo.

Due to waiting for the line for unloading in terminals, document checking, inspection, transshipping, another $2 \%$ is lost in the yard and other compartments in the ports.

In the loading and unloading, another $2 \%$ is lost in the yard and other compartments in the ports.

Source: adapted from Freitas (2007), Souza et al. (2012) and Machado (2012).

As can be seen in Table 5, the hidden costs can appear in all the operations (harvesting, storing, boarding process, procedures bureaucracy, outdated technology and low rate of equipment maintenance), and those costs can also be generated by the performance of unskilled staff.

Machado (2012) estimates that from the harvesting to the draining of soy, there is a loss from $5.95 \%$ to $15 \%$. Among them, the hidden costs that represent operational matters are embedded in order $2 \%$, storing $5 \%$ and transport $5 \%$ (CARVALHO, 2015).

Based on the data found and considering that the annual soy draining volume by waterway mode, São Simão Port/GO to Pederneiras/SP, is 2 million metric tonnes of grains, the hidden costs from grains loss hit 119 to 300 thousand metric tonnes of soybean and it is equivalent to a loss between US $\$ 33,002.13$ and US $\$ 83,275.28$.
}

[http://creativecommons.org/licenses/by/3.0/us/]

Licensed under a Creative Commons Attribution 3.0 United States License 
DOI: 10.14807/ijmp.v7i2.418

Measuring up these costs must be closely analyzed because the results obtained may represent an inaccurate percentage.

\section{CONCLUSIONS}

Waterways are an important mode of transport, for products with low benefit, for the unexpansive costs it represents. In this assignment, we identified that the direct, indirect and hidden costs for road mode transport as an alternative to the Tietê-Paraná Waterway corresponds to a meaningful increase.

In relation to the hidden costs, we conclude that they represent an increase of $10 \%$ in transportation costs, bearing in mind problems such as losses, delays and products that spoil along the transport.

However, the data gathered show that the rate of losses, which are considered as hidden costs, occur between $5.95 \%$ and $15,00 \%$, which is above the maximum accepted by FAO (Food and Agriculture Organization) which suggests that they be below 13\% (FAO, 2015).

In order to reduce those losses, cut down on the direct, indirect and hidden costs and increase soybean producers competitive, operations to normalize navigation level for Tietê-Paraná Waterway are necessary. Water flow reduction of three hydropower plants in order to raise the level of the reservoirs along Paraná River thus making it possible to continue navigation through this waterway.

The road mode alternative has been proven not to be suitable because the freight cost variation, journey time, and reliability is too large, over encumbering the operation.

Considering the importance of Tietê-Paraná Waterway, be it for competitively of an economic activity or for the development of a region, it is necessary to assess the need for investments in order to mitigate complications, both related to infrastructure or weather-related, as the drought we have been facing, for instance.

This work intended to assess the impact of the costs in the transference from waterway to Road mode, revealing the importance of a suitable transport structure and the need to study more deeply, aiming at precisely describing each step of the process and make a comparison of costs in relation to other countries which own the 
DOI: $10.14807 /$ ijmp.v7i2.418

same matrix of production, transport and storing and that can be more competitive showing smaller costs.

\section{REFERENCES}

AMARAL, M. S.; CORDEIRO NETTO, O. M. (2013) Empreendimentos e atividades hidroviários: entraves históricos e questões ambientais. In: SIMPÓSIO BRASILEIRO DE RECURSOS HÍDRICOS, 20, Bento Gonçalvez. Anais... Bento Gonçalvez: ABRH, 2013.

AGÊNCIA NACIONAL DE TRANSPORTES AQUAVIÁRIOS - ANTAQ (2014) Anuário estatístico de 2013: navegação interior. Brasília: ANTAQ, p. 48.

AGÊNCIA NACIONAL DE TRANSPORTES AQUAVIÁRIOS - ANTAQ (2013) Anuário Estatístico Aquaviário: Navegação Interior - cargas, empresas e frota. Brasília: ANTAQ, p. 34.

BRASIL. Ministério dos Transportes (2013). Plano Hidroviário Estratégico - Relatório do Plano Disponível em: <http://www.transportes.gov.br-/conteudo/91224> (Acesso em: 12 de out. 2015).

CARVALHO, D. (2009) Desperdício- Custo para todos - Alimentos apodrecem enquanto milhões de pessoas passam fome. Revista Desafios do

Desenvolvimento. Ano 6, Ed. 54.

CARVALHO, R. O.; ROBLES, L. T.; ASSUMPÇÃO, M. R. P. A. (2010) Logística Integrada na Prestação de Serviços de Cabotagem: de porto a porto para o porta a port. In: Simpósio de Administração da Produção, Logística e Operações Internacionais - SIMPOI, 13, São Paulo. Anais... São Paulo: SIMPOI, 2010.

CHOPRA, S.; MEINDL, P. (2011) Gestão da cadeia de suprimentos: estratégia, planejamento e operações. São Paulo: Pearson, p. 536.

DIAS, M. A. P. (2010) Administração de Materiais: uma abordagem logística. São Paulo: Atlas, p. 544.

DUTRA, R. G. (2010) Custos: uma abordagem prática. São Paulo: Atlas, p. 448.

FOOD, NATIONS, A. O. of the U., DE LUCIA, M., ASSENNATO, D. (1994) Agricultural engineering in development : post-harvest operations and management of foodgrains, FAO Agricultural Services Bulletin. Food and Agriculture Organization of the United Nations. Disponível: <http://www.fao.org /docrep/t0522e/T0522E04.htm\#Post-harvest\%20losses $\geq$. (Acesso em: 12 de out. 2015).

FREITAS, J. B.; SEVERIANO FILHO, C. (2007) Apreciação dos custos ocultos do processo sucroalcooleiro em uma usina de álcool na Paraíba. Revista Gestão Industrial. v. 3, n. 1, p. 52-63.

INSTITUTO DE LOGÍSTICA E SUPPLY CHAIN - ILOS (2014) Panorama Custos Logísticos no Brasil. Rio de Janeiro: ILOS, p. 200.

OLIVA, J. A. B. (2009) Panorama das hidrovias brasileiras, In: Seminário Internacional sobre Hidrovias Brasil - Holanda, 1, Brasilia, Anais... Brasilia: Seminario ANTAQ, 2009. 
KUSSANO, M. R.; BATALHA, M. O. (2012) Custos logísticos agroindustriais: avaliação do escoamento da soja em grão do Mato Grosso para o mercado externo. Gestão da Produção. São Carlos, v. 19, n. 3, p. 619-632.

MACHADO, S. T. (2012) Perdas na produção de soja brasileira: uma análise do ponto de vista da estratégia de rede de suprimentos enxuta. Especialização. Curitiba: UFPR.

POMPERMAYER, F. M.; CAMPOS NETO, C. A. S; DE PAULA, J. M. P (2014) Hidrovias no Brasil: perspectiva histórica, custos e institucionalidade. Rio de Janeiro: IPEA, p. 58.

PROTASIO, P. (2009) $15^{\circ}$ Fórum da Associação Brasileira de Agribusiness. Agroanalysis - Revista de Agronegócios da FGV, jun. 2009, p. 36-41. Disponível em: http://bibliotecadigital.fgv.br/ojs/index.php/agroanalysis/article/viewFile/26917/ 25790. (Acesso em: 12 de out. 2015).

REIS, J. G. M.; TOLOI, R. C.; FREITAS, M. J. (2015) Análise da Viabilidade de Custos do Transporte de Soja de Mato Grosso via Hidrovia Tietê Paraná, In: $1^{\circ}$. Encontro Interestadual de Engenharia de Produção, 1, São João da Barra, Anais... São João da Barra: EINEPRO, 2015.

SALOMÃO, R. (2012). Transporte de soja fica mais barato no Brasil pela primeira vez desde 2003, aponta levantamento. Disponível em: <http://www.canalrural.com.br /noticias/agricultura/transporte-soja-fica-mais-barato-brasil-pela-primeira-vez-desde2003-aponta-levantamento-39222>. (Acesso em 05 de out. 2015).

SCHNEPF, R. D.; DOHLMAN, E.; BOLLING, C. (2001) Agriculture in Brazil and Argentina: developments and prospects for major field crops. USDA, p. 85.

SILVA, P. C. P.; FILHO, C. S. (2011) Ocorrência de custos ocultos em operações de serviços: insights sobre observação em uma sociedade de economia mista no Brasil, Revista Gestão da Produção, São Carlos, v. 18, n. 3, p. 499-508.

SOUZA, M. A.; ALBERTON, J. R.; MARQUEZAN, L. H. F.; MONTEIRO, R. P. (2011) Fatores de ocorrência de custos ocultos: estudo em uma cooperativa gaúcha agroindustrial de arroz, In: V Congresso da Associação Nacional dos Programas de Pós-Graduação em Ciências Contábeis, 5, Vitoria, Anais...Vitoria: ANPCONT, 2011.

TEIXEIRA, P. F. (2010) Desempenho de terminais hidroviários do corredor logístico centro-oeste: um estudo de multicascos. Dissertação (Mestre em Administração). Campo Grande: UFMS.

TOKARSKI, A. (2014) Navegação interior no Brasil e o avanço dos Investimentos públicos e privados, In: $1^{\circ}$ Reunião de Câmara Temática de 2014, Brasilia, Anais... Brasilia: Reunião de Câmara Temática de 2014, ANTAQ, 2014.

TOMAZELA, J. M. (2014). No interior, seca quebra safras, para industrias e encalha a hidrovia. Disponível em: <http://saopaulo.estadao. com.br/noticias/geral,no-interiorseca-quebra-safras-para-industrias-e-encalha-hidrovia,1542806>. (Acesso em 06 de out. 2015).

TREVISAN, K. (2015). Com seca, produtores trocam hidrovia por caminhões e têm prejuízo. Disponível em: <http://g1.globo.com/economia/crise-da-agua/noticia/2015 /03/com-hidrovia-fechada-transporte-em-caminhoes-gera-prejuizo-produtores.html>. (Acesso em: 07 ago. 2015). 
INDEPENDENT JOURNAL OF MANAGEMENT \& PRODUCTION (IJM\&P)

http://www.ijmp.jor.br

v. 7, n. 2, April - June 2016

ISSN: 2236-269X

DOI: 10.14807/ijmp.v7i2.418

U.S. DEPT. OF AGRICULTURE - USDA. Brazil Transportation Guide.

Washington, 2012.

WANKE, P. (2010) Logística e transporte de cargas no Brasil: produtividade e eficiência no Século XXI. São Paulo: Atlas, p. 200.

WORLD WIDE INLAND NAVIGATION NETWORK (2010). SOUTH AMERICA: Us inland waterways. WWINN.ORG. Available em: <http://www.wwinn.org/us-inlandwaterways>. (Acesso em: 01 out. 2015). 